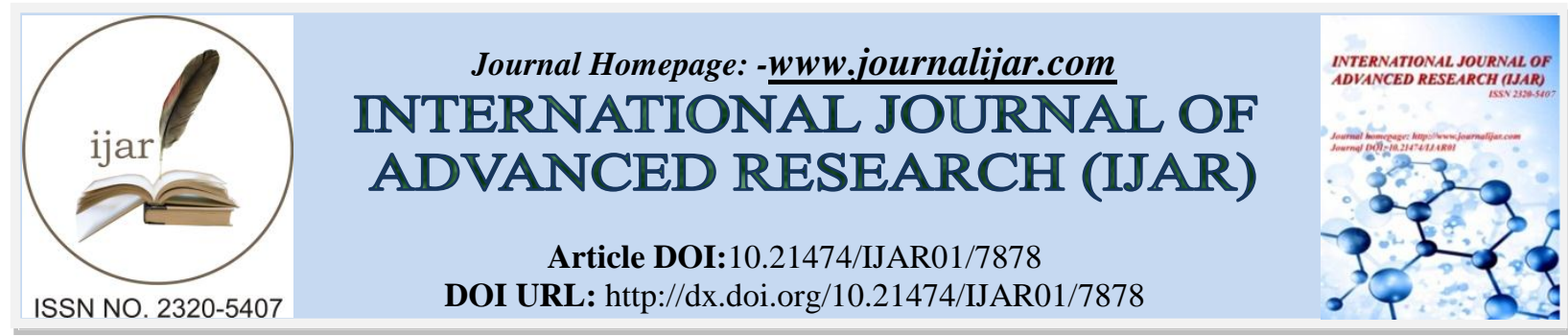

RESEARCH ARTICLE

\title{
VALUE BASED EDUCATION: A NEED OF PRESENT SOCIETY.
}

\author{
Reyaz Ahmad Bhat. \\ Research Scholar, School of Studies in Philosophy, M.L.BGovt College of Excellence, Jiwaji University Gwalior, \\ M.P.
}

\section{Manuscript Info}

\section{Manuscript History}

Received: 10 August 2018

Final Accepted: 12 September 2018

Published: October 2018

Keywords:-

education, value, society, value based education.

\begin{abstract}
Value education means inculcating in the children a sense of humanism that would build the nation and bring back to the people pride in work that brings order, security and assured progress. Present age is age of science and technology there is a great confusion and great losses. War and conflicts never come to an end, and the innumerable vicious phenomena are covering the world. The cause of such confusion and loses is due to the lack of value oriented education or the collapse of traditional views of values. In this paper an attempt is made to discuss the need of value based education in a present society. In this study it was carried out how one might study and modify a society to make it peaceful and more functional. In the present educational system the main emphasis is giving on scientific and information oriented education rather than value education. Spiritual values, social values, moral values and religious values are being neglected. Value suffers when too much emphasis is giving on materialistic satisfaction. The aim of this paper was why there is a need for imparting value based education in educational institutions and to develop the programs for inculcating values insociety. This paper tried to examine the role of value based education on inculcating code of ethics to develop the qualities of good conduct, self-confidence, unity, cooperation, justice, peace and prosperity in present society. This paper is aimed at to impart value based education in educational institutions, family and society as well and to churn out good citizens for the maintenance of world peace and harmony.
\end{abstract}

Copy Right, IJAR, 2018,. All rights reserved.

\section{Introduction:-}

Search for values is an essential cultural quest of the humankind. It is a quest into the nature of that 'goodness' which gives worth, dignity and nobility to human existence. All the good education is, in essence, a process of developing the human personality in all its dimensions-intellectual, physical, social, moral and spiritual. But in the recent times, our education could not focus on the effective dimensions of the personality. Value education, therefore, need to be reoriented towards developing in the child knowledge, skills, attitudes, values and behavior patterns that society considers desirable for him to have, both as an individual and as a member of society. Therefore, education in its aims, curriculum and methods should be inseparably, bound up with values. Society expects to preserve and promote its values through education through desirable changes in the child's way of thinking, feeling and in the way he acts in accordance with good life. 
The present society is entering into a short of Dark Age because of essential values and increasing of cynicism in society. To overcome this difficulty, value education should be included in the curriculum and there is the need of a comprehensive programme of value education which can enable students to meet new situations in the world of values, not only as they are now, but also in any new situation that may arise in future. The importance of value oriented education is to understand and bring highly commendable values and wisdom in the students. It is an integral part of intellectual development.

All the commissions and committees on education in India have invariably commended value education. The Kothari commission (1964-66) specifically stressed this aspect. The National policy on education 1986 (modified in 1992) re-asserts this element. Taking note of the present day "erosion of essential values" and the consequent "growing cynicism in the society", it calls for necessary readjustments, changes in the system of education, to make it "a forceful tool for the cultivation of social and moral values".

\section{Concept of educational values}

Anything or everything which, for instance, is of significance and importance for education, has a bearing on education contribution to its constructive side, serves as a unit in its formative aspect, is of value.

In other words, activities that are good, useful and valuable from, educational point of view are considered as educational values. Therefore in student learning centers attitudes and habits are cultivated developed and formed having utilitarian value. Education, as we know is a much wider conception than teaching. It is a whole of which teaching is a part. Teaching, which is concerned with instruction, influences pupils to the existing value system. The 'educator pole' influences the 'educated pole'. "Hence education has for its aim to modify the nature of the educand, and not merely to supply a certain amount of knowledge." J.Ruskin has expressed similar views on educational values. According to him, "education does not mean's teaching people to know that they do not know, it means teaching them to behave as they do not behave". Thus the ultimate aim of education is to achieve good life. Aims are ends in themselves and values are the products. Without aim or an objective no purposeful activity can be achieved. After we have fixed our aim and objective for a particular thing we devise methods and devises to achieve at the desirable goal. When we reach the goals we call it values. Thus in the field of education values are the results that we actually obtain. Teachers and students are engaged in such activities that they think to be educationally useful and valuable.

\section{Value and education}

Value and education are closely related, in fact, are the two sides of the same coin. The entire educational system and the educative process are a manifestation, revelation and realization of values considered worthwhile by individual and society, from time to time. Aims of education, curriculum,etc. are the expanded and explicit forms of values. Values are the beacons, the guiding principles, finding their culmination and consummation in the educative process.

Values are life-oriented, education is life-related, hence values and education have similarity of purpose, both inspiring man towards a pre-determined goal. According to Reid, "Education is a part of life, and clearly our questions of about values and education inseparable from questions of values in life. Values inculcate sense of discrimination between right and wrong, between good and bad; so does education. Any worthwhile education system, in the final analysis, must aims at making man a better person. The very idea of better refers to a valuesystem according to which aprocess, thing, experience or, person is better. Education is based on values, and values are realized through education.

Value based education means inculcating in the children a sense of humanism, a deep concern from the well-being of others and nation. This can be accomplished only when we instill in the children a deepfeeling of commitment to values that would build this country. Through value education we like to develop the social, moral, aesthetic and spiritual sides of a person which are often undermined in formal education. Value education teaches us to preserve whatever is good and worthwhile in what we have inherited from our culture. It helps us to accept the respect attitude and behavior of those who differ from us.

Value based education has the capacity to transfer anunhealthy mind into a very young, fresh, innocent, healthy natural and attentive mind. The transformed mind is capable of higher sensitivity and a heightened level of perception. 
This leads to fulfillment of the evolutionary role in man andValues are standards or principles considered important in life. They come from within and also by practicing. They are the foundation of human existence. Society cannot sustainwithout the proper guidance of values. Values tell a man to differentiate between good and evil, what one should do and what one should abstain from. They make our life meaningful.

\section{Education and society}

In layman's language, the term 'society' means a number of individuals acting together and influencing one another. It is an enduring group of living beings, carrying on all the activities in common under the same basic circumstances of living within a geographical territoryand bound together by certain common experiences and cultural ideas.

Webster's universal dictionary defines society as a "system whereby men live in organized communities, regulated by custom and law, for purpose of mutual protection, help, government etc. with the division of labour to ensure that the various necessities of life are provided and its essential activities are carried on.

Society is an organism of individuals or persons. It is spiritual organization of free persons. "Human society", Green says, "is essentially a society of self-determined persons. The individuals cannot live apart from the society. The society also is not possible apart from individuals.

Every education act is part of a process directed towards an end. These ends are dictated by general, ultimate aims which are laid down by society. Individuals- learners, teachers, parents - exert a conscious or unconscious influence on the way the ultimate aims of education aredetermined or modified.

Education plays an important part in preparing men for life in society andmoldingthem accordingly, weather directly or indirectly. It moves the individual learners into a coherent moral, intellectual and effective universe composed of sets of values, interpretations of the past andconcept of the future. At the same time, it provides a fundamental store of ideas and information.

Precisely, all educationists agree to the fact that there should be a balanced synthesis between the social and the individual goals are the common orientation.

Education has continued to evolve diversity and extend its coverage since the dawn of human history. It assists in acquiring knowledge about the self, society and environment and helps an individual builds better relationships with all the three. Every country develops its system of education to express and promote its unique socio-culture identity and also history when a new direction has to be given to an age-old process. That moment is today.

"Education is the process in which an individual is working into fruition of its own nature; it is a man's mean to realize his destination, his goal of largest power, joy and services". Education is the emancipation from ignorance. It emancipates the person from the tyranny of the small self and the educated person becomes altruistic and social. Education is the influence of the environment upon the individual. Such influence brings a change in his habits of behavior, thought and attitude. Education enables an individual to develop all those capacities which enable him to control his environment, adjust himself to his environment and realize his possibilities and fulfill them in a socially desirable manner.

\section{Need for value based education}

With the starting of $21^{\text {st }}$ century, different kinds of changes had taken place in the human life all over the world which brought many changes in the social values. The phenomenon of industrialization and globalization has given rise to issue of justice, freedom, equality and human rights etc. today's society has become highly materialistic. Only the monetary considerations are in the mind of institution and the students. In the absence of regard for values, crime, violence, greed have spread to all aspects of human life. Now a days, India'spolitical and social life is passing through a phase, which possess the danger of erosion to long accepted values.

National policy of education (1986) has emphasized the need of value- oriented education and commented that India, being a culturally plural society, 'education should foster universal and eternal values, oriented towards the unity and integration of our people, Such value education should help eliminate obscurantism, religious fanaticism, violence, superstition and fatalism. 
The education system of any country plays an essential role in the preservation, transmission and inculcation of values. It is a continuous and creative process and helps us in all walks of life-personal, professional, social and national. But today the primary focus of education is to provide material knowledge. In the present education system of our country the main stress is giving on money making rather than man making, our education system is dominated by economic values. The present education system, however, through its mechanistic approach has added to human psychological problems which through its formal and non-formal agencies has developed an apparatus of structures, content and processes to transmit knowledge without much concern or commitment to respond to the task of communicating and inculcating values necessary for creating ideological climate congenial to appreciation of cultural heritage and taking pride in one's history and having confidence in human capability to overcome material, social, religious and spiritual problems of living.

Our educational institutions at all levels are laboring hard for their survival and continuance under serious problem and it is felt that such problems as exist in these institutions, are a reflection of common problems in the community. The students of today have been deprived of their roots with the result that they have failed, by and large, to identify themselves with the community.

Education does not consist merely in the imparting of text-book knowledge or preparing the child for a career, however important these goals are. The moral and spiritual foundations or which we structure our educational system alone can mould the future destiny of the country. As Swami Vivekananda said 'we need a man-making and nation building education.

Under the educational system which is currently in vogue in our country the emphasis is solely on the imparting of knowledge concerning the academic subjects included in the curriculum, and no attention is usually paid to the development of the child's character and inner personality. The result is that children group up without getting any opportunity to know about the glorious cultural traditions of our country and the great moral and spiritual values on which that culture is based.

The importance of imparting education in human values to the younger's has always been felt and emphasized by all great religious teachers, educationists, social reformers and all other sorts of humanists in varying degrees, in one way or the other way, throughout the world in all ages. But at the present juncture of the history of human civilization its important has become extremely acute and critical due to riotous interplay of diverse economic, technological, political, cultural and sociological factors causing an unprecedented moral; decay and socialdisorganization. The education systems in India and almost everywhere in the world are miserably failing to work for the spiritual, moral and social upliftment of men.

The present education system, with all its complexities and intricacies, has proved to be deficient in so far as it neglects, or does not give the deserving importance to values in human life. Thus human suffering and sorrows are forever on the increase in spite of the phenomenal explosion of knowledge. Values have become the neglected lot in the present education system.

"Education without vision is waste; education without value is crime; education without mission is life burden". Education in our life enables us to become comfortable and to look after our family well. But so far as the social progress is concerned, value-based education is unavoidable necessity. "A nation with atomic power is not a strong nation; but a nation with people with strong character is indeed a strong nation. If a nation is to be a strong, then the character of the people of that nation needs to be elevated. For this purpose value-based education is an indispensable device".

\section{Implementation of values}

The inculcation of values is by no means a simple matter. There is no magic formula, technique or strategy for this. Value education in all its comprehensiveness involves developing sensitivity to values, an ability to choose the right values, internalizing them, realizing them in one's life and living in accordance with them. Therefore, it is not a time-bound affair. It is a lifelong quest. Inculcation of values is influenced by a complex network of environment factors such as home, school, peer group, community, and the media at large. Home takes the highest position in the hierarchy followed by school. 
Value education, as a joint venture requires collaborative efforts of parents, teachers, teacher educators, administrators, curriculum planners etc. as it develops social cohesion and unity because the content of value education cannot be found only in the text but in the ways adopted as methodologies on the part of teachers or learning styles from students' perspectives, organization of curricular and co-curricular activities in the realm of administrators and curriculum planners and of course parental involvement with proper cooperation with school authorities.

In the task of value-formation of students there are two distinct steps that have to be taken by an educational institution. One is making available to the students appropriate reading material e.g. biographies and views of great men who had before them certain values and ideals of life and who practiced them against all odds and making all sacrifices including in some cases even their very life. The other and the most important thing to make education, as far as possible, an effective agency of value orientation is the institutional ethos and the personal examples provided by the teachers. The institutional ethos is built up primarily by the values that the organizers and the heads of the institutions actually practisedwhile running the institution. The teachers and other workers working in the institution will naturally be influenced by the values practiced by the organizers and their heads who, by personal examples, would be able to do a lot in developing a right type of institutional ethos. The students would also have a role to play. Education process involves an exchange of personality at both the ends, the student on the one and the teacher on the other.

\section{Sources of value education}

There are many different sources, which can be utilized by the teacher to impart value education. They are as follows:

1. Regular subjects of the school curriculum are the first source of value education. Whatever subjects we teach, there is a set of values, which is hidden in structure and methodology. The teacher will have to find it out and accordingly impart instructions. For example, General science is associated with such values as free inquiry, commitment to truth and mathematics with such qualities of mind as logical thinking, neatness and precisions, similarly literature and history have their own distinctive values. The correct teaching of the subject, involve and not only transmission of the information contented in the subject but even more importantly including in the learner, the qualities of mind and heart involved in the pursuit of that discipline. Thus subject can be used as a source of value education.

2. Co-curricular activities are the second important source for the development of values in school children with its multifarious programs, which are not only packed with education and instruction, but also provide young pupils with opportunities for self-expression and self-fulfillment.

3. The students- self-government in school, NCC,NSB, Boy Scouts and Girls Guides, Red- Cross, the various clubs and associations, games and sports, excursions and field visits, all provide opportunities for the students to come together in the pursuit of common goals and ideals. Besides the development of creativity and distinctive intellectual, social, and cultural interests, students also learn from these activities, the value of democratic living, co-operation, tolerance, and responsibility. These activities provide experience in learning values through actual living.

4. The environment is the third source of value education. Some great Indian personalities in like Tagore, Gandhi and Sri Aurobindo laid much stress on the creation of a conducive environment in the Centre's of learning for the development of personality of the students. The personal examples and hard work of the teachers, the ideals of the teachers, peoples and the parents help the students to acquire right values in life. It is the teacher who has to provide the right environment in the school and impart values in the students by the different methods and techniques.

\section{Conclusion:-}

From the above discussion it can be concluded that value education plays an important role in the present social scenario of our society. Values are closely relative to the reality of life and help us to solve the life related problems in our present society. Let us consider our present education system; we find that value has lost their place in our education system. In our present education system much more emphasis is given in the technical knowledge and information oriented education as compared to value education. Due to this traditional values and religious values has lost their faith. Violence, crimes, murders, hate, disturbance and terrorism are rampant all around. People are getting violent not in India but all over the world, not only uneducated people but educated people are also involved. In order to overcome these problems value education should be implemented and it is the responsibility of every one to inculcate values in youngsters, like family, teacher, school, society, higher authorities etc. If we want to make a 
good community or want to became a well-mannered person, and to make a peaceful society of a good human conduct, then we should have to focus with keen interest on value oriented education for its implementation in our present education system, because it can help us to gain some unity and harmony between present and past experience, and to reach a position, which shall satisfy the demands of feeling and reflection, mind and intelligence, and give men self-confidence and courage, for facing the future.

\section{References:-}

1. Shukla R.P. (2004), "value Education and Human Rights". Pub. By Sarup and sons 4740/23, Ansari road Darya Ganj New Delhi, p.6

2. Kar N.N.(1996), "Value Education”, a philosophical study. Pub. By: D.K. Vaid for the associated publishers, Kacha Bazar, post box no. 56, Ambala cantt.133001 (India).

3. RAM ATMA "Education for Development" (1995), Pub. By Vikas Publishing House Pvt. Ltd 576 Masjid Road, Jangpura, New Delhi- 110014, p, 13

4. Panchal R.K, "Education and society". Pub. By Independent publishing company sadar bazaar, Delhi (2007) P199

5. Chadha Lt. Col. (Dr.) Satish c. "Educational values and value education", pub. By VI nay Rakheja c/o R. Lall Book Depot. Begum Bridge Road Meerut- 250001, (2014) p, 25

6. R.A. Sharma. "Human Values and Education", (axiology, inculcation \& research) pub. By. Vinay Rakheja c/o Ra all books depot. Meerut, (2014) P.3, 4

7. Taneja V.R, "Social philosophical Approach to Education". Pub. By Atlantic Publishers \& Distributors (p) LTD. Ansari Road Darya Ganj, New Delhi- 110002. Copy right, 2003, 2005, 2012. P. 4

8. Sinha Jadunath, "introduction to philosophy" pub. ByNew Central Book Agency (p) Ltd. $4262 / 31^{\text {st }}$ floor flat Nos. 105 \& 106 Ansari Road Daryaganj New Delhi. Revised edition (1985) p, 217

9. Sharma Dr. Shrinath, Singh Dr. Manoj Kumar, (2000),"Education and Society" pub. By Akansha Publications Pathak Ward, Bina Madhya Pradesh, (2000) p, 92, 93.

10. Mat too Dr. M.I. "Foundations of Education". Part-2, (2005) Pub. By M/S Book Vision, Srinagar Kashmir p.22

11. Dr. Neha, "necessity of value oriented education in present scenario" International journal of education \& applied research. ISSN: 2348-0033-(online)/ ISSN: 2249- 4944 (print) IJEAR VOL-6, issue 1, spl-1, Jan-June 2016.

12. Venkataiah Dr. N. "value education" pub. By A P H Publishing Corporation Ansari Road Darya Ganj New Delhi- 110002 (2007) p.12

13. AhujaDr. Amit "Need of value education for a global society", Amity international journal of teacher education vol-2, No.1, April (2016) p, 3

14. Ruhela Dr. Satya Pal, "human values and education", (1986) Pub. By Sterling publishers private Limited L-10, Green Park Extension, New Delhi- 110016, p, 4

15. Kumar Sajit Gagan M.“Teaching and Research Aptitude”.Pub. By Danika Publishing Company 4352/4c, Ansari Road, Daryaganj, New Delhi- 110002- revised edition (2018) p, 525,526. 